J. Perinat. Med. 17 (1989) 461

\section{Determination of light-chain myosin in pregnancy and under toco- lysis}

\author{
Wolfgang Lechner', Erika Artner-Dworzak², Kurt Heim¹, Christian Marth', and \\ Bernd Puschendorf ${ }^{2}$
}

${ }^{1}$ Department of Obstetrics and Gynecology, ${ }^{2}$ Institute of Medical Chemistry and Biochemistry, University of Innsbruck, Austria

\section{Introduction}

Besides pulmonary edema, myocardial damage is mostly feared during tocolytic treatment with betasympathomimetic agents. In 1959, RoNA described infarct-like lesions under isoproterenol in the rat [15]. Also in man, myolyses, nuclear fadings and other hypoxic lesions have been reported $[1,2,3,17]$. Polytope ventricular extrasystoles, ST-depression and T-flattenings have been found in ECG $[6,18]$. These pathologic events, if diagnosed, often lead to discontinuation of tocolysis resulting in the birth of a premature child $[8,9]$.

Numerous laboratory investigations have been performed on cardiac side effects of betamimetics. In our laboratory, no change in heart-specific CK-MB under ritodrine-verapamil [10], but impressive increases of myoglobin under hexoprenaline without cardioprotective agents [11] were observed. In contrast, no change of serum myoglobin could be demonstrated, if the beta ${ }_{1}$-blocking substance metoprolol or the calcium-entry blocker verapamil were added to the betamimetics $[12,13]$.

In ongoing search for an even more specific diagnosis of ischemic myocardial lesions, the determination of heart specific light-chain Lmyosin was performed by means of a monoclonal antibody [7]. Using this antibody, we had the opportunity to investigate L-myosin under tocolysis with hexoprenaline-metoprolol in comparison with uncomplicated pregnancies for the first time.

\section{Curriculum vitae}

WOLFGANG LECHNER, M.D., was born in Innsbruck, Austria, in 1943 and did his medical studies in Innsbruck and Munich. After having made his general practitioner, he specialised in obstetrics and gynecology in the Universities of Vienna and Innsbruck. His main scientific work

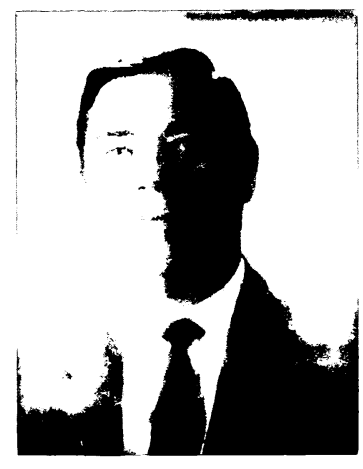
included investigation of new substances for tocolytic purposes, including alpha-blockers, phosphodiesterase inhibitors, calcium antagonists and recently developed progestagens.

\section{Material and methods}

L-myosin was determined using a recently developed monoclonal antibody in 51 women with uncomplicated pregnancies in the $28^{\text {th }}-41^{\text {st }}$ week of gestation. In 15 healthy women, who were treated with intravenous infusion containing hexoprenaline $(0.3 \mu / \mathrm{min})$ and metoprolol $(0.01$ $\mathrm{mg} / \mathrm{min}$ ) because of threatening premature birth, plasma L-myosin was investigated before as well as 2, 6, 12 and 24 hours after beginning of tocolysis.

Blood was drawn into EDTA tubes. After centrifugation, plasma was freezed at $-20^{\circ} \mathrm{C}$. Lmyosin concentration was measured by means of a recently developed enzyme-immuno-assay of BOEHRINGER/MANNHEIM, FRG, on ES22 (Enzyme-immuno-assay system 22 ). 


\section{Results}

The results derived from normal pregnancies are demonstrated in table I. Figure 1 shows the Lmyosin values before and 2, 6, 12 and 24 hours after the beginning of tocolysis with hexoprenaline-metoprolol. There is an increase in the median and $90^{\text {th }}$ percentile values, but no statistically significant difference between these values

Table I. Plasma L-myosin values in pregnant women $(\mathrm{ng} / \mathrm{ml}), \mathrm{n}=51$

\begin{tabular}{ll}
\hline median & 0.98 \\
$20^{\text {th }}$ percentile & 0.28 \\
$80^{\text {th }}$ percentile & 1.60 \\
min. & 0 \\
max. & 3,50 \\
\hline
\end{tabular}

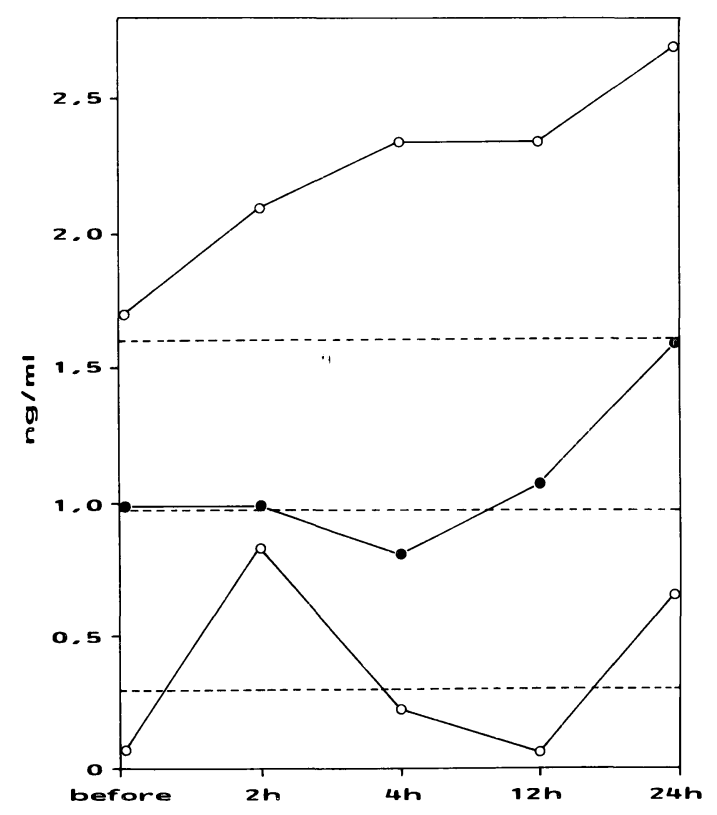

Figure 1. L-myosin values in 15 patients before and under tocolysis with hexoprenaline-metoprolol compared to 51 controls (dotted lines: median, $20^{\text {th }}$ and $80^{\text {th }}$ percentile of controls). and the normal ones could be shown (range variance analysis after KRUSKAL-WALLIS, [16]).

For ethical reasons, we did not treat patients with hexoprenaline alone, because we had found impressive increases of myoglobin values during monotherapy with beta-sympathomimetics [11].

\section{Discussion}

Together with actin, myosin is working as a contractile protein in heart, sceletal and smooth musculature. The molecule is about $1600 \AA$ in length, its weight is about 500000 daltons. It consists of two parts: a) the head, which is composed of two "heavy chains" with two "light chains" each and is able to hydrolize ATP and to enter into connection with the corresponding actin-molecule and b) the tail which consists of two helical protein chains transmitting the contractions caused by the head onto the myofilaments. The contractile state of a muscle is defined by the phosphorylation or dephosphorylation of the myosin light chains by a corresponding kinase or phosphatase. The myosin light chain kinase is activated by $\mathrm{Ca}^{++}$-calmodulin $[4,5]$.

There are several organospecific forms of myosin. Their heavy chains (MW 200000 daltons) are common, and they differ in their lightchains. L-myosin specific for myocardium has a molecular weight of 12000 daltons. It exists in two forms: free cytosolic L-myosin is raising in the serum 3-6 h after a myocardial necrosis has taken place, while particular-bound L-myosin levels are high from 22 hours up to two weeks [7]. L-myosin being liberated independently from the perfusion in contrast to $\mathrm{CK}-\mathrm{MB}$ and myoglobin represents most precisely the number of destroyed cardiomyocytes and therefore it is the best marker for the extension of the destroyed myocardial area [14]. Another significant point is the above mentioned possibility to verify it up to two weeks.

These investigations show that a hypoxic myocardial damage can be widely excluded for a tocolysis with hexoprenaline-metoprolol. 


\begin{abstract}
Cardiac toxicity of tocolysis containing hexoprenaline $(0.3 \mu \mathrm{g} / \mathrm{min})$ and the beta ${ }_{1}$-blocking agent metoprolol $(0.01 \mathrm{mg} / \mathrm{min})$ was investigated using a recently developed monoclonal antibody arised against light-chain myosin in 15 patients and compared with the results
\end{abstract}

in 51 control subjects. There was an increase in the median and $80^{\text {th }}$ percentile values $2,6,12$ and 24 hours after the beginning of tocolysis but no statistically significant difference between these values and the normal ones could be shown.

Keywords: Light-chain myosin, myocardial damage, tocolysis.

\section{Zusammenfassung}

Bestimmung der Myosin-L-Ketten in der Schwangerschaft und bei Tokolyse

Ein Myokardschaden ist eine der schwerwiegendsten Komplikationen bei der Tokolyse mit betamimetischen Substanzen. Die Laboruntersuchungen umfassen die Bestimmung der Creatinin-Kinase-MB, der Myoglobine und, seit neuestem, der L-Ketten im Myosin durch einen monoklonalen Antikörper. Wir bestimmten das L-Myosin im Plasma von 15 sonst gesunden Frauen, die intravenös Hexoprenalin $(0,3 \mu \mathrm{g} / \mathrm{min})$ und Metoprolol $(0,01 \mathrm{mg} / \mathrm{min})$ erhielten. Die Blutentnahmen erfolgten vor sowie 2, 6, 12 und 24 Stunden nach Beginn der Tokolyse. 51 Frauen ohne Komplikationen in der Schwangerschaft bildeten die Kontrollgruppe. Wir beobachteten einen Anstieg des Medianwertes und der Werte der 80er Perzentile, jedoch ließen sich keine statistisch signifikanten Unterschiede im Vergleich mit der Kontrollgruppe sichern (Abb. 1).

Zusammenfassend konnten wir bei unseren Patientinnen, die eine Tokolyse mit Hexoprenalin und Metoprolol erhielten, Myokardnekrosen ausschließen.

Schlüsselwörter: Myosin-L-Ketten, Myokardschaden, Tokolyse.

\section{Résumé}

Détermination de la myosine a chaine légère au cours de la grossesse et pendant la tocolyse

Les lésions myocardiques représentent une des complications les plus graves au cours de la tocolyse par bétamimétiques. Les examens de laboratoire comprennent les mesures de la créatinine kinase, des myoglobines et, depuis peu, de la (L)myosine à chaîne légère à l'aide d'un anticorps monoclonal. Nous avons dosé la LMyosine dans le plasma de 15 femmes, bien portantes par ailleurs, traitées par perfusion intra-veineuse d'hexoprenaline $(0,3 \mu \mathrm{g} / \mathrm{min})$ et de metoprolol $(0,01$ $\mathrm{mg} / \mathrm{min}$ ). Les prélèvements sanguins ont été effectués $2,6,12$ et 24 heures après le début de la tocolyse. 51 femmes sans complications gravidiques ont servi de témoins. Il existe une augmentation de la moyenne et des valeurs du 80ème percentile, mais pas de différence statistiquement significative en comparaison avec les témoins (figure 1).

$\mathrm{Au}$ total, chez nos patientes sous tocolyse par hexoprenaline-metoprolol, on peut éliminer une nécrose myocardique.

Mots-clés: Lésions myocardiques, myosine à chaîne légère, tocolyse.

\section{References}

[1] Bender HC, G Goeckenjan, CH Megu, H MüNTEFERING: Zum mütterlichen Risiko der medikamentösen Tokolyse mit Fenoterol (Partusisten ${ }^{\mathrm{R}}$ ). Geburtsh u Frauenheilk 37 (1977) 665

[2] BENEDETTI TJ: Maternal complications of parenteral beta-sympathomimetic therapy for premature labor. Am J Obstet Gynecol 145 (1983) 1

[3] Harms K, S Heinzl, D Radakovic, M SchneiDER: Perinatale Medizin VII. G. Thieme, Stuttgart 1976

[4] HARTSHORNE D: Regulation of Smooth Muscle Actomyosin. Blood Vessels 19 (1982) 1

[5] HuSZAR G, JM ROBERTS: Biochemistry and pharmacology of the myometrium and labor: Regu- lation at the cellular and molecular levels. Am J Obstet Gynecol 142 (1982) 225

[6] Junge HD, H Kords, CH RodT: Materne und fetale EKG-Veränderungen bei Partusisten-Infusion sub partu. Perinatale Medizin II, G. Thieme, Stuttgart 1976

[7] KaTus HA: Myosinleichtketten: neue Markerproteine für die serologische Infarktdiagnostik. Lab med 11 (1987) 149

[8] Katz M, PA Robertson, RK Creasy: Cardiovascular complications associated with terbutaline treatment for preterm labor. Am J Obstet Gynecol 139 (1981) 605 
[9] Kiesewetter E: In: Deutsch, E, K UrSigler, O KraUPP (eds): Hexoprenalin. Springer Verlag, Wien-New York 1970

[10] LECHNER W, F DIENSTL: Myokardschäden unter Tokolyse? WiKliWoSchr 91 (23) (1979) 798

[11] LeChNer W, F DienstL, W PoeWe, G DaXenbichLER: Myoglobinanstieg unter Tokolyse. WiKliWoSchr 92 (14) (1980) 502

[12] LeChNER W, F DienstL, G DAXENBICHLER: Myoglobinverhalten unter Tokolyse. Z Geburtsh u Perinat 183 (1981) 321

[13] LeChNER W, G DAXENBICHLER: Myoglobinverhalten unter Hexoprenalin und Betablockade. Z Geburtsh u Perinat 188 (1984) 226

[14] Puschendorf B: Myoglobin, L-Myosin, atrialer natriuretischer Faktor, cGMP. Neue Parameter für kardiologische Diagnostik. Lab Med 12 (1988) 191
[15] Rona G, CI Chappel, T Balazs, R Gandry: An infarct-like myocardial lesion and other toxic manifestations produced by isoprotenerol in the rat. Arch Path 67 (1959) 443

[16] SACHS L: Angewandte Statistik. Springer-Verlag, Berlin-Heidelberg-New York 1978

[17] TROLP R: Kasuistischer Beitrag zur möglichen Herzschädigung nach Tokolyse. Perinatale Medizin VII. Thieme Verlag, Stuttgart 1976

[18] Wellstein A, H Breinl, $\mathrm{K}$ Meinen, EW SCHMIDT: Zur Frage der Myokardschädigung durch Fenoterol. Z Geburtsh u Perinat 181 (1977) 402

Received August 23, 1989. Accepted October 16, 1989.

Doz. Dr. Wolfgang Lechner Univ.-Klinik für Frauenheilkunde Anichstr. 35

A-6020 Innsbruck 